\title{
Game farms as sustainable ecotourist attractions
}

\author{
P. VAN Der Merwe and M. SaAyman
}

Van der Merwe, P. and M. Saayman. 2005. Game farms as sustainable ecotourist attractions. Koedoe 48(2): 1-10. Pretoria. ISSN 0075-6458.

The main goal of this research was to determine aspects that will contribute to the development of sustainable ecotourism on game farms. In order to achieve this, empirical research was done by means of a survey sample consisting of all the active members of the South African Game Farmers Organisation. There are a total of 1244 members, of whom $50 \%(n=622)$ were randomly sampled for the research. In the main findings of the research, aspects were identified that are developed according to the criterion for sustainable ecotourism. These aspects include natural/conservation/environmental considerations as well as cultural aspects, such as learning local languages. Aspects that are neglected include working closely with the local community to develop new products; developing partnerships and joint ventures in which the community has a significant stake; fostering the development of community-based tourism products by providing marketing and mentoring support; and considering using local entrepreneurs in the development of community initiatives.

Key words: game farm tourism, ecotourism, sustainable development, tourism

$P$ van der Merwe (ontpvdm@puk.ac.za) and M Saayman, North-West University: Potchefstroom Campus, School of Entrepreneurship, Marketing and Tourism Management: Institute for Tourism and Leisure Studies, Private Bag X 6001, Potchefstroom, 2520 Republic of South Africa.

\section{Introduction}

For international as well as local tourists, scenic beauty and wildlife remain the major tourism attractions that South Africa has to offer (GCIS 1998; GCIS 1999). Ecotourism is responsible for $20 \%$ of the world's total tourism expenditure. According to the World Tourism Organisation (WTO), the fastest growing of all tourism sectors is any form of tourism in an area of unspoilt nature (Van Zyl 1999). In southern Africa, there is also an increasing awareness of the importance of wildlife, as well as the socio-economic advantages of well-conserved wildlife. This shows that ecotourism is an important product for South Africa and a drawcard for international as well as local tourists. Van der Merwe (2004), points out the important role of game farms in ecotourism and conservation.

A game farm is defined as land that is adequately fenced, with a variety of game species that can be used for hunting, photographic opportunities, environmental education, meat production, live game sales and which provides infrastructure and suprastructures for ecotourists. It includes both consumptive and non-consumptive utilisation of wildlife (Van der Merwe \& Saayman 2004). Eloff (2000) and Fox \& du Plessis (2000) have found that $80 \%$ of nature conservation in South Africa is taking place on privately owned land, such as game farms, and according to Bothma (2002) there was a $2.5 \%$ increase in land utilised for game farming from 1998 to 1999 . The latter translates into an increase of 300000 ha per year. Flack (2002b) reports that it is estimated that the conversion rate from cattle to game farming was nearly 500000 ha in 2002, which is 200000 ha more than the 1998 to 1999 increase.

South Africa has in fact experienced a sharp increase in the supply of game over the past decade because of the growth in game farms and private reserves as well as the fact that one hardly found any game on farms in the 
previous century (Eloff 2002, 2003, 2004). In 2000 , it was estimated that there were approximately 7000 privately-owned game farms in South Africa, with a total surface area of 16 million ha (Ebedes 2002), of which 5061 were exempted game farms, with a surface area of 10364154 ha (Erasmus 2000). Research conducted in 1993 indicated that the surface area of exempted game farms constituted $8.5 \%$ of the total agricultural land in South Africa, which increased to $12.5 \%$ in 2000 , with a total of $1.7 \mathrm{~m}$ head of game (Eloff 2002; Erasmus 2000). Statistics for 2002 showed that $13.3 \%$ of the agricultural land was used for game farming, while national and provincial game reserves only covered $6 \%$ or $6.1 \mathrm{~m}$ ha of land in South Africa (Flack 2002a; Van der Walt 2002).

The wildlife sector in South Africa differs considerably from the rest of the world in the sense that game farm tourism is practised with indigenous species that are privately owned. In addition, it seems that game farm tourism in South Africa is better controlled and regulated (Fox \& Du Plessis 2000). Sustainable tourism is based on three pillars namely, economic efficiency, environmental conservation and social equity (Coccossis et al. 1996). Furthermore, Coccossis et al. (1996:9) indicated that from a sustainability point of view it is important that money generated from consumptive use (for example hunting) of wildlife is ploughed back into ecotourism, local communities and nature conservation. Due to a lack of research in this regard it is not known whether this is taking place in South Africa.

McIntosh et al. (1995) also argue that, to be competitive, it is important for game-farm owners to develop competitive products that are sustainable in the long term. Van der Merwe \& Saayman (2001) also indicate that in order to be competitive game farms should concentrate on ecotourism, breeding game and rare/endangered game species, processed game products, and hunting (Fig. 1). This will also enhance their level of economic sustainability. Van der Merwe (2004) identified a variety of activities that may be applied by game-farm owners (Fig. 1).

According to Van der Merwe \& Saayman (2004), the type or combination of activities on a game farm is determined by a number of aspects, for example the size and location of the farm, climate, infrastructure and number of game. These authors have found that more activities may result in more income, but that the environment also largely determines which activities can be provided (Van der Merwe \& Saayman 2001).

Eloff (2001), Eloff (1999), Du Plessis (2000), Hamman et al. (2003), Saayman \& Van der Merwe (2005) and Schack (2004) identified a number of problems that game farms are currently experiencing and that will impact on sustainability. These problems include:

- over-dependence on game;

- game farms that are too small to allow for greater variety of activities;

- cross-breeding or hybridisation;

- freak animals;

- Rand / Dollar exchange rate;

- Fire-arms Control Act;

- slow implementation of National Qualifications Framework;

- long delays for checking in at international arrivals;

- low level of domestic awareness of game farm ecotourism;

- little diversification;

- unregulated relocation of animals;

- lack of tourism knowledge;

- game farm owners in general stick to traditional services, for example hunting and breeding of game;

- lack of game farmers working together to create a better product for tourists;

- lack of involvement and disinterest among game farm owners. Game farm owners are not part of regional or national organisations. As a result they are unaware of the latest developments in the industry.

Briassoulis (2002) argues that sustainable tourism development revolves around the central issue of how to manage the natural, built, and socio-cultural resources of host 


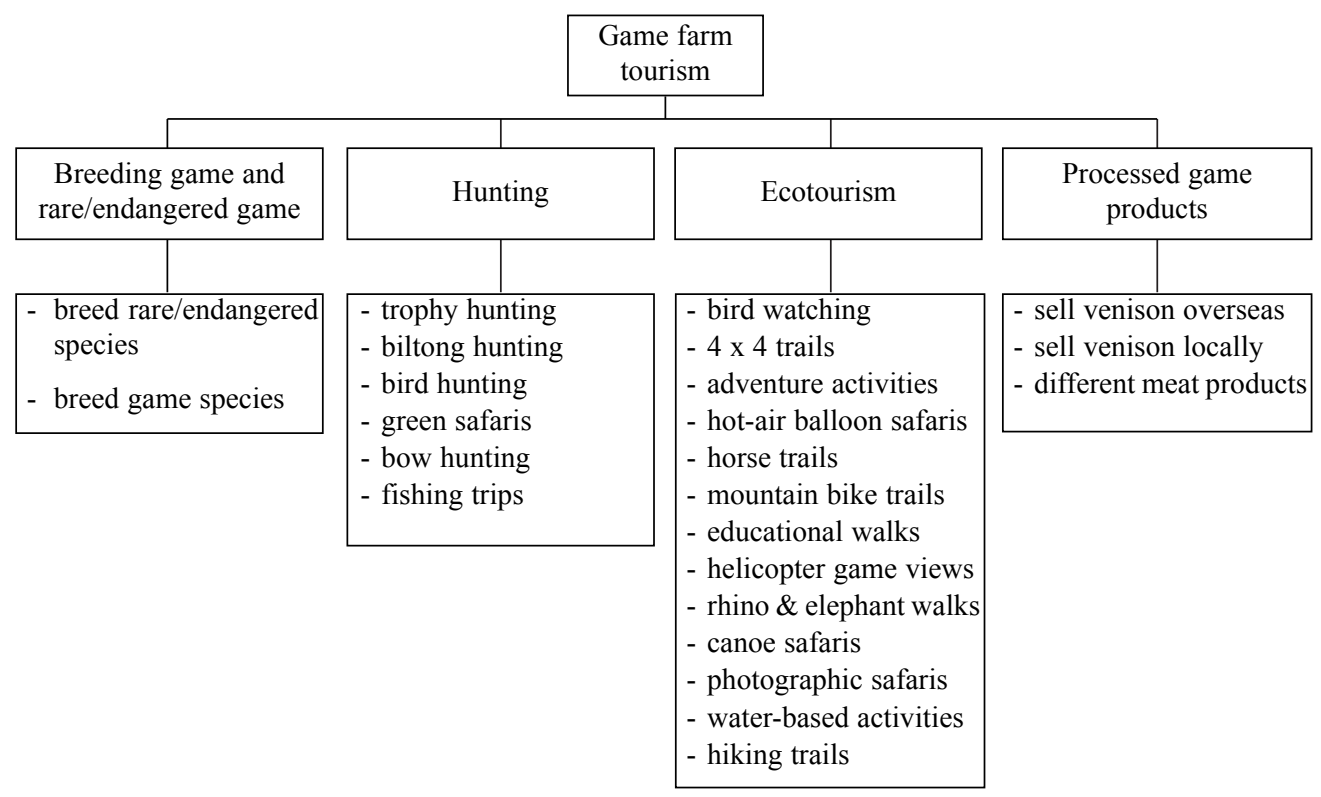

Fig. 1. Four pillars of game farm tourism.

communities in order to meet the fundamental criteria of promoting their economic wellbeing, preserving their natural and socio-cultural capital, achieving intra and inter-generational equity in the distribution of costs and benefits, securing their self-sufficiency, and satisfying the needs of tourists.

Sustainable tourism development may be seen as tourism development which is responsibly planned and managed. It is the exact opposite of tourism that has been developed for short-term gains (Myburgh \& Saayman 1999). According to Goodwin (2002), there are three primary requirements for sustainable tourism. Firstly, it must meet the needs of the host community in terms of standards of living (short and long term); secondly, it must satisfy the demands of increasing tourist numbers and continue to attract them in order to achieve an improved standard of living; and thirdly, it must safeguard the environment for this purpose. Thus, to achieve true sustainable ecotourism development, one must find a delicate balance between conflicting economic efficien- cy, environmental conservation and social equity objectives. The resulting economic growth must be distributed equably, and the environmental impacts of these actions must be minimised. The 'three E's' of sustainable tourism may be best explained by a triangle that represents policy. Each vertex portrays an imaginary situation in which policy is exclusively dominated by one goal, economic efficiency, social equity or environmental conservation (Fig. 2).

The first analysis of sustainable tourism may be identified as the policy area near the vertex corresponding to economic efficiency. The second analysis, ecologically sustainable tourism, may be identified near the vertex corresponding to environmental conservation. The third is really a combination of economic efficiency and environmental conservation policies and may be identified somewhere along the side connecting these two vertices of the triangle. The last analysis seems to fit better in the centre of the triangle. There is no one, ideal tourism strategy. The above-mentioned approaches reflect dif- 


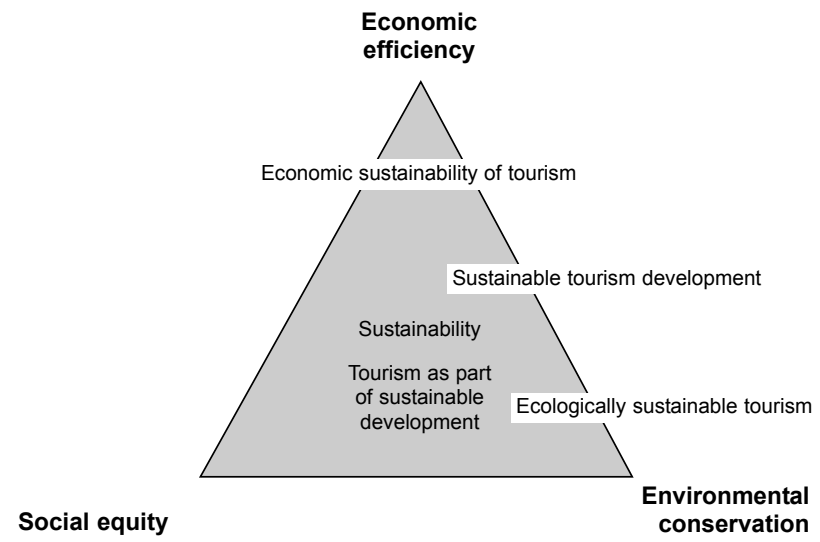

Fig. 2. Analysis of sustainable tourism (Adapted from Coccossis et al. 1996).

ferent priorities of which each has its own merits and could be appropriate for different cases and settings, whether mature or emerging destinations, in growth or decline, natural areas or developed resorts (Coccossis et al. 1996).

If game-farm owners stick to the above-mentioned aspects, they will contribute to achieving the goals of sustainable tourism development, which are explained by Inskeep (1991) as follows:

- to develop a greater awareness and understanding of the significant contributions that game farm tourism can make to the environment, the people and the economy;

- to promote equity in development;

- to improve the quality of life of the host community;

- to provide a high quality of experience for the visitor;

- to maintain the quality of the environment on which the foregoing goals depend.

The outcome of these factors will indicate which aspects are neglected and will impact on the sustainability of game farms in South Africa.

\section{Methods}

Based on the literature review (Hobson \& Essex 2001; Mohasi 1999; Harris \& Leiper 1995; Myburgh \& Saayman 2002; Milne 1998; Yunis 2001; Coetzee 2004) a questionnaire was developed with a total of seventy-three items covering sustainability. The questionnaire made use of two different Likert scales. The first was a five-point scale and was used to determine the importance of the different activities on game farms, where $1=$ not at all important and $5=$ extremely important. The second Likert scale was a three-point scale and was used to test the importance of the different sustainable development aspects, where $1=$ not important; and $3=$ very important.

The empirical research was conducted from June 2003 until March 2004. The survey sample included all the active members of the South African Game Farmers Organisation, namely:

- Northern Game Farmers Organisation, with 645 members (Gauteng, North West, Limpopo, and Mpumalanga);

- Free State Game Organisation, with 250 members;

- Northern Cape Game Organisation, with 109 members;

- Natal Game Ranchers Association, with 120 members;

- Western Cape Game Management Association, with 20 members;

- Eastern Cape Game Management Association, with 100 members. 
In a pilot study, ten questionnaires were administered so as to identify possible constraints and problems. Modifications were then made to develop the final questionnaire.

The membership added up to a total of 1244 , of which $50 \%(n=622)$ were randomly sampled for the research. A questionnaire was sent to each of the selected respondents via e-mail or fax. Members were also visited in person during various workshops that were held by the South African Game Farmers Organisation. A total of 97 questionnaires were received from the selected 622 members. The low response rate ( $15 \%$ response) was ascribed to the fact that game farm owners were unwilling to complete the questionnaire. To increase the return rate of questionnaires, many follow-up phone calls were made and e-mails were sent to the different game farmers associations and respondents, to request them to complete and return the questionnaires. However, this also had little success.

The statistical analysis involved statistical processes such as Cronbach alpha (factor analysis) and effect sizes for the relationship in contingency tables (Phi coefficient) (Steyn 2000). The Cronbach alpha statistical process is of major importance for this research. The programme that was used is for statistical analysis was SAS Institute Inc. (SAS System for Windows Release 9.1 TS Level 1M0).

\section{Results}

Firstly, the activities of game farms will be discussed, and secondly the application of the aspects of sustainable development will be addressed.

\section{Importance of activities}

Respondents had to rate the variety of activities that are currently applied on game farms (Table 3). The following activities were rated as very important to extremely important by respondents:

- $\quad$ breeding game species (69\%);

- offering trophy hunting $(60 \%)$;

- breeding rare/endangered species (47\%);

- $\quad$ hunting game for biltong (45\%);

- offering 'green' safaris (39\%).

Traditional activities, for example biltong hunting or trophy hunting, remain the most
Table 3

Activities according to scale of importance

\begin{tabular}{|c|c|c|c|c|c|}
\hline $\begin{array}{l}5 \text { - Extremely important } \\
4 \text { - Very important } \\
3 \text { - Important } \\
2 \text { - Less important } \\
1 \text { - Not important at all }\end{array}$ & & & & & \\
\hline Activities & 1 & 2 & 3 & 4 & 5 \\
\hline $\begin{array}{l}\text { Breeding rare/ } \\
\text { endangered species }\end{array}$ & 21 & 20 & 12 & 20 & 27 \\
\hline Breeding game species & 2 & 8 & 21 & 29 & 40 \\
\hline Offering trophy hunting & 14 & 10 & 16 & 24 & 36 \\
\hline Hunting game for biltong & 22 & 18 & 15 & 23 & 22 \\
\hline Offering bird hunting & 38 & 24 & 19 & 8 & 11 \\
\hline Offering green safaris & 29 & 12 & 20 & 18 & 21 \\
\hline Offering bow hunting & 26 & 18 & 17 & 22 & 17 \\
\hline Offering fishing trips & 61 & 11 & 10 & 13 & 5 \\
\hline Selling venison overseas & 44 & 16 & 12 & 8 & 20 \\
\hline $\begin{array}{l}\text { Selling venison local } \\
\text { market }\end{array}$ & 35 & 13 & 22 & 17 & 13 \\
\hline Providing bird watching & 13 & 17 & 25 & 22 & 23 \\
\hline Providing hiking trails & 16 & 20 & 26 & 20 & 18 \\
\hline $\begin{array}{l}\text { Offering photographic } \\
\text { safaris }\end{array}$ & 20 & 18 & 31 & 10 & 21 \\
\hline Providing $4 \times 4$ trails & 45 & 20 & 16 & 11 & 8 \\
\hline $\begin{array}{l}\text { Providing adventure } \\
\text { activities }\end{array}$ & 33 & 22 & 24 & 10 & 11 \\
\hline $\begin{array}{l}\text { Providing hot-air balloon } \\
\text { safaris }\end{array}$ & 58 & 26 & 10 & 3 & 3 \\
\hline Providing horse trails & 41 & 13 & 21 & 12 & 13 \\
\hline $\begin{array}{l}\text { Providing mountain bike } \\
\text { trails }\end{array}$ & 44 & 20 & 21 & 7 & 8 \\
\hline $\begin{array}{l}\text { Providing educational } \\
\text { walks }\end{array}$ & 23 & 15 & 30 & 19 & 13 \\
\hline $\begin{array}{l}\text { Other } \\
\text { - Helicopter game views } \\
\text { - Rhino and elephant walks } \\
\text { - Canoe safaris } \\
\text { - Game drives with ranger }\end{array}$ & & & & & \\
\hline
\end{tabular}

important. This supports the notion that game farm owners do not utilise all four pillars, namely breeding game; hunting (trophy and/or biltong); game sales; and selling game products. This also implies that activities such as walking safaris, horse riding, educational talks, mountain bike trails and hiking do not form part of their product base. A reason for not implementing the four pillars could be that game farms are too small 
Table 4

Factor analysis

Conservation and resources

\section{Factor 1}

Factor loading

\section{Factor 2}

Local culture / architectural Factor loading

0.80 B5DD Avoid noise or light pollution 0.85

0.79 B3DD Visits by local school $\quad 0.82$

0.77 B5EE Buildings with natural ventilation $\quad 0.72$

0.76 B3MM Visitor safety 0.70

$0.74 \quad$ B3AA Respect nature, local culture $\quad 0.70$

0.73 B3LL Hospitality 0.69

$0.73 \quad \mathrm{~B} 3 \mathrm{HH} \quad$ Local flavour $\quad 0.68$

0.72 B3JJ Tourists learning a few words 0.67

0.72 B4AA Commercialisation and 0.62 over-exploitation.

0.68 B711 Keep local character 0.61

0.68 B5FF Teach visitors about 0.55 environmentally friendly conduct

0.60 B3FF Showcase local cultural artefacts $\quad 0.53$

B4II Ensure that tourism does not undermine local resources

0.56 B4BB Respect local culture $\quad 0.52$

$\begin{array}{lll}0.55 & \text { B3EE } & \text { Scholarships }\end{array}$

B4CC Use local guides 0.49

B6JJ Assist conservation through 0.41 sustainable trails

\section{Factor 3}

Involvement: tourists/ host community

\begin{tabular}{ll}
\hline B2KKCC & $\begin{array}{l}\text { Cooperation relationship: } \\
\text { businesses sector }\end{array}$ \\
B2KKDD & $\begin{array}{l}\text { Cooperation relationship: } \\
\text { local government }\end{array}$
\end{tabular}

B2KKEE Cooperation relationship: government
0.73

$0.72 \quad$ B6DD

0.63
Factor 4

Environmentally friendly Factor products

Minimise packaging loading

loading

0.84

0.82

B6EE

Reduce consumption of

0.80 natural resources

0.79

B6GG

Recycling waste produced

0.79

BII Reduce "food miles"

0.78 local culture

B2KKBB Cooperation relationship: tourists

B4DD sources 
Table 4 (continued)

\begin{tabular}{|c|c|c|c|c|c|}
\hline & \multicolumn{3}{|l|}{ Factor 3 (continued) } & \multicolumn{2}{|l|}{ Factor 4 (continued) } \\
\hline & $\begin{array}{l}\text { Involvement: } \\
\text { tourists/host community }\end{array}$ & $\begin{array}{l}\text { Factor } \\
\text { loading }\end{array}$ & & $\begin{array}{l}\text { Environmentally friendly } \\
\text { products }\end{array}$ & $\begin{array}{l}\text { Factor } \\
\text { loading }\end{array}$ \\
\hline B2KKAA & $\begin{array}{l}\text { Cooperation relationship: } \\
\text { local community }\end{array}$ & 0.60 & B4JJ & $\begin{array}{l}\text { Negative cultural impacts - } \\
\text { monitored }\end{array}$ & 0.64 \\
\hline B2JJ & $\begin{array}{l}\text { Monitor progress in } \\
\text { achieving objectives }\end{array}$ & 0.59 & $\mathrm{~B} 6 \mathrm{FF}$ & Monitor sewage & 0.61 \\
\hline B4KK & $\begin{array}{l}\text { Educate tourists about } \\
\text { local culture }\end{array}$ & 0.58 & B5AA & Plan new developments & 0.49 \\
\hline B1BB & $\begin{array}{l}\text { Create revenue from } \\
\text { cultural heritage }\end{array}$ & 0.56 & & & \\
\hline B3KK & $\begin{array}{l}\text { Complementary product } \\
\text { opportunities }\end{array}$ & 0.55 & & & \\
\hline B4FF & $\begin{array}{l}\text { Provide visitors with } \\
\text { reliable information }\end{array}$ & 0.52 & & & \\
\hline \multirow[t]{3}{*}{ B1AA } & Extend the season & 0.48 & & & \\
\hline & Factor 5: & & & Factor 6: & \\
\hline & Local community & $\begin{array}{l}\text { Factor } \\
\text { loading }\end{array}$ & & Environmental issues & $\begin{array}{c}\text { Factor } \\
\text { loading }\end{array}$ \\
\hline B2EE & Community-based tourism & 0.81 & B5II & Minimise environmental impact & 0.72 \\
\hline B2II & $\begin{array}{l}\text { Be transparent - community } \\
\text { benefits }\end{array}$ & 0.72 & B5BB & Environmentally friendly products & 0.72 \\
\hline $\mathrm{B} 2 \mathrm{HH}$ & Use local entrepreneurs & 0.69 & B5JJ & $\begin{array}{l}\text { Environmentally friendly } \\
\text { guidelines for construction firms }\end{array}$ & 0.71 \\
\hline B2BB & Partnerships with community & 0.69 & B5HH & Planting local indigenous species & 0.65 \\
\hline $\mathrm{B} 2 \mathrm{FF}$ & $\begin{array}{l}\text { Visitors to spend more } \\
\text { money - local economy. }\end{array}$ & 0.65 & $\mathrm{~B} 5 \mathrm{CC}$ & Local materials & 0.64 \\
\hline B2AA & Local community products. & 0.64 & B3BB & $\begin{array}{l}\text { Tourism - catalyst for } \\
\text { human development }\end{array}$ & 0.63 \\
\hline $\mathrm{B} 2 \mathrm{CC}$ & $\begin{array}{l}\text { Identify projects - } \\
\text { benefit the poor }\end{array}$ & 0.62 & B5KK & Fines - contractors & 0.59 \\
\hline B2DD & $\begin{array}{l}\text { Development of the local } \\
\text { community }\end{array}$ & 0.61 & B7HH & $\begin{array}{l}\text { No tourists into ecologically } \\
\text { sensitive areas }\end{array}$ & 0.59 \\
\hline B5MM & $\begin{array}{l}\text { Conserving fresh water } \\
\text { resources }\end{array}$ & 0.58 & $\mathrm{~B} 3 \mathrm{CC}$ & $\begin{array}{l}\text { Respect for social/ } \\
\text { cultural/religious rights }\end{array}$ & 0.41 \\
\hline B2GG & $\begin{array}{l}\text { Including shebeens, } \\
\text { museums and arts/craft }\end{array}$ & 0.57 & & & \\
\hline B5LL & $\begin{array}{l}\text { Avoid environmentally } \\
\text { dangerous substances }\end{array}$ & 0.53 & & & \\
\hline B3II & $\begin{array}{l}\text { Cultural history - } \\
\text { local community }\end{array}$ & 0.49 & & & \\
\hline B3GG & $\begin{array}{l}\text { Maintain the authenticity } \\
\text { and cultural values }\end{array}$ & 0.45 & & & \\
\hline
\end{tabular}


to host all four pillars. Game-farm owners are possibly also uninformed in terms of ecotourism as well as the needs of tourists in general. Research by Van der Merwe \& Saayman (2001) showed that the majority of game farm owners are not trained and educated in the field of tourism. These results support the above findings and confirm that most game farms $(56 \%)$ were converted from cattle or crop farms.

\section{Factor analysis (Chronbach Alpha)}

A factor analysis was conducted for the results regarding sustainable ecotourism development. Six factors were identified (Table 4 ), and $75.5 \%$ of the total variance in the data was explained by the six factors. All factor loadings above 0.4 were obtained from the data (Table 4), which is significant.

- Factor one: conservation and resources. Game farms constituted approximately $12.5 \%$ of the total agricultural land in South Africa in 2000. This increased to $13.3 \%$ in 2002 , with a total of $1.7 \mathrm{~m}$ head of game, while national and provincial game reserves only covered $6 \%$ or 6.1 million ha of land in South Africa (Eloff 2002; Erasmus 2000; Flack 2002a; Van der Walt 2002). Hence, game farm owners are clearly very aware of their role in conservation.

- Factor two: local culture and architecture, which include aspects such as visits by local schools, respect for nature and local culture, a local flavour, retaining the local character and learning a few words of the local language. Researchers such as Hobson \& Essex (2001); Mohasi (1999); Harris \& Leiper (1995); Myburgh \& Saayman (2002); Milne (1998) and Yunis (2001) emphasise these aspects as part of sustainable tourism.

- Factor three: the relationship between tourists and the host community. Relevant aspects here are cooperation with local government and national government, interaction between visitors and local culture, cooperation with the local community and the education of tourists regarding the local cul- ture (Hobson \& Essex 2001; Pigram \& Wahab 1997).

- Factor four: the use of environmentally friendly products. It was indicated that it is important to minimise packaging that can harm nature, reduce the consumption of natural resources, recycle waste, reduce food miles and monitor sewage and energy from non-renewable resources.

- Factor five: the local community. The following aspects had a high loading factor: community-based tourism, using local entrepreneurs, partnerships with the local community, visitors spending more money in the local community, buying local community products and visiting shebeens and local museums.

- Factor six: environmental issues, such as minimising environmental impacts, environmentally friendly products, local indigenous species and not taking tourists into ecologically sensitive areas. This goes hand in hand with conservation and hence it is rated as important by game farmers.

Table 5 shows the mean and standard deviation, indicating that all factors are considered important to very important, considering the scale that was used in the questionnaire $(1=$ not important; $2=$ important; $3=$ very important). This is also evident in columns six and seven of Table 5 , where the minimum was 1 and the maximum 3. Factors that respondents consider very important (column 3 of Table 5) are factors one (conservation and resources; mean 2.44), two (local

Table 5

Standard deviation of factors

\begin{tabular}{lcccccc} 
Factor $n$ & Mean & $\begin{array}{c}\text { Standard } \\
\text { deviation }\end{array}$ & $\begin{array}{c}\text { Coefficient } \\
\text { of variation }\end{array}$ & Min. Max. \\
\hline 1 & 75 & 2.44 & 0.45 & $18 \%$ & 1 & 3 \\
2 & 77 & 2.33 & 0.46 & $19 \%$ & 1 & 3 \\
3 & 82 & 2.20 & 0.44 & $20 \%$ & 1 & 3 \\
4 & 74 & 2.26 & 0.53 & $23 \%$ & 1 & 3 \\
5 & 81 & 2.11 & 0.51 & $24 \%$ & 1 & 3 \\
6 & 78 & 2.37 & 0.39 & $16 \%$ & 1 & 3 \\
\hline
\end{tabular}


culture/architecture; mean 2.33) and six (environmental issues; mean 2.37). Factor five (local community) was not deemed as important as the other factors (mean 2.11).

\section{Conclusion}

The primary objective of this research was to determine aspects that will contribute to the sustainable ecotourism development of game farms. These aspects were identified as natural/conservational/environmental considerations as well as cultural aspects, such as learning local languages. Aspects that are neglected were: working closely with the local community to develop new products; developing partnerships and joint ventures in which the community has a significant stake; fostering the development of communitybased tourism products by providing marketing and mentoring support; and using local entrepreneurs in developing community initiatives. Failure to address aspects like these could result in negative community relationships and even poaching, due to unemployment and poverty.

The majority of game farms (56\%) were converted from stock/cattle farms to game farms and have been managed as game farms for $1-10$ years $(64 \%)$. The high conversion rate has resulted in a situation where the majority of game-farm owners were not trained and educated in tourism. This is in line with other research on tourism-related issues. It also supports the notion that game farmers do not have the required skills to manage tourism as part of game farms.

The contribution of this research is captured below.

Firstly, the statistical analysis of the results gauged the most important aspects of sustainable development as rated by game farmers: (a) promote and ensure respect for and dignity of people in the development, marketing and promotion of tourism; (b) promote a sound, proud service ethic among all participants in the tourism sector; and (c) avoid damage to the environmental quality of the enterprise's neighbourhood by noise or light pollution.

Secondly, aspects that need attention and are neglected by game farm owners were also identified. The most important of these are the development of partnerships and joint ventures with the local community; encouraging tour operators to be more innovative in their itineraries by, for example, including shebeens, local museums and arts and craft shops in their tour itineraries; and identifying projects that can support entrepreneurial activities.

Lastly, this research was among the first of its kind in South Africa and has laid the foundation for further research to be accommodated in this field of study.

\section{References}

Bothma, J. DU P. 2002. Some economics of wildlife ranching. Pp. 23-29. In: PENZHORN, B.L., (ed.). Game ranch planning and management. Symposium held at Onderstepoort, Pretoria on 1-2 Nov. 2002. Pretoria: Wildlife group of South African Veterinary Association.

Briassoulis, H. 2002. Sustainable tourism and the question of the commons. Annals of Tourism Research 29(4):1065-1085. Oct.

Coccossis, H., J.A. Edwards \& G.K. Priestly. 1996. Sustainable tourism: European experiences. Guilford: Biddles.

Coetzee, W.J.L. 2004. An integrated sustainable tourism development strategy for the Vredefort Dome as a World Heritage Site. Ph.D thesis, North-West University, Potchefstroom.

Du Plessis, P.C. 2000. Game farmers not concerned enough. SA Game \& Hunt 6(7): 9. Jul.

Ebedes, H. 2002. Preface. Pp. 7-9. In: Ebedes, H., B. Reilly, W. van Hoven \& B. Penzhorn (eds.). Sustainable utilization-conservation in practice. Proceedings of the 5th International wildlife ranching symposium held at Pretoria on 20-23 March 2001. Pretoria: South African Game Ranchers Association.

Eloff, T. 1999. Professionalisme in die wildbedryf. KLK Nuus 29(1): 9. Jan.

ElofF, T. 2000. Die omvang van die wildbedryf in Suid-Afrika. PU vir CHO. Potchefstroom Ongepubliseerd.

ElofF, T. 2002. The economic realities of the game industry in South Africa. Pp. 78-86. In: EBEDES, 
H., B. Reilly, W. van Hoven \& B. Penzhorn (eds.). Sustainable utilization-conservation in practice. Proceedings of the 5th International wildlife ranching symposium held at Pretoria on 20-23 March 2001. Pretoria: South African Game Ranchers Association.

ElofF, T. 2003. Gemiddelde wildveilingpryse 2002. Wild \& Jag 9(2): 21. Feb.

Eloff, T. 2004. Game sales 2003 in South Africa. Africa Indaba 2(2): 5. Mrt.

ERASMUS, S.D. 2000. Die ekonomiese lewensvatbaarheid van ' $n$ wildvleisbewerkingsaanleg in Suid-Afrika. M.Com. verhandeling, PU vir $\mathrm{CHO}$, Potchefstroom.

FLACK, P.H. 2002a. The conservation revolution. Game \& Hunt 8(10): 29-33. Oct.

Flack, P.H. 2002b. Exotic game - catching up with Texas? Magnum: 76-80. Oct.

Fox, T. \& P. DU Plessis. 2000. Hunting in southern Africa. Africa Indigo 3(3): 40-47.

GCIS (GOVERNMENT COMMUNICATION AND INFORMATION System). 1998. South Africa Official Yearbook. Cape Town: Rustica.

GCIS (GOVERNMENT COMMUNICATION AND INFORMATION System). 1999. South Africa Official Yearbook. Cape Town: Rustica. 576 p.

Goodwin, H. 2002. Contribution of ecotourism to sustainable development in Africa. WTO seminar on planning, development and management of ecotourism in Africa. Maputo, Mozambique held on 5-6 March 2001.

Hamman, K., S. VRahimis \& H. Blom. 2003. Can current trends in the game industry be reconciled with nature conservation? African Indaba 1(5): 3-5. Sep.

HARRIS, R. \& N. LEIPER. 1995. Sustainable tourism: an Australian perspective. Chatswood: Butterworth.

Hobson, K. \& S. Essex. 2001. Sustainable tourism: a view from accommodation businesses. Service Industry Journal 21(4): 133-146. Oct.

INSKEEP, E. 1991. Tourism planning: an integrated and sustainable development approach. New York: Van Nostrand Reinhold.

Mcintosh, R.W., C.R. Goeldner \& J.R. Ritchie. 1995. Tourism, principles, practices and philosophies. New York: Wiley. 551 p.
Milne, S.S. 1998. Tourism and sustainable development: exploring the global-local nexus. Pp. 3549. In: Hall, C.M. \& A.A. LeW (eds.). Sustainable tourism. Harlow: Prentice Hall.

MoHAsi, L. 1999. Adventure travel and sustainable tourism development in Lesotho: the case of pony trekking. M.Sc. dissertation, University of Natal, Pietermaritzburg.

Myburgh, E. \& M. SaAyman. 1999. Ecotourism in action: practical guidelines and principles. First Edition. Potchefstroom: Leisure Consultants and Publications.

Myburgh, E. \& M. SAAYMAn. 2002. Ecotourism in action: practical guidelines and principles. Second Edition. Potchefstroom: Leisure Consultants and Publications.

Pigram, J.J. \& S. Wahab. 1997. The challenge of sustainable tourism growth. Pp. 3-13. In: Wahab, S. \& J.J. Pigram (eds.). Tourism, development and growth. London: Routledge.

SaAyman, M. \& P. van der Merwe. 2005. Gun laws and its impact on the sustainibility of the hunting industry. Wildlife and hunting symposium: facing challenges, 6 July, 2005. Lephalale: DBSA.

SCHACK, W. 2004. Wildboerdery van wêreldgehalte: algemene filosofie, potensiaal, bedreigings, doelwitte. Wild \& Jag 10(4): 22-25. Apr.

SteYN, H.S. (jr.) 2000. Practical significance of the difference in means. Journal of Industrial Psychology 26(3):1-3.

VAn DER Merwe, P. \& M. SAAYMan. 2001. Managing game farms from a tourism perspective. Potchefstroom: Ons Drukkers.

VAN DER Merwe, P. 2004. Game farms as sustainable ecotourism attractions. Ph.D thesis, North-West University, Potchefstroom.

VAN Der Merwe, P. \& M. SAaYMan. 2004. Managing game farms from a tourism perspective. Potchefstroom: Leisure C Publications.

VAN DER WALT, J. 2002. Proliferation of game ranches. Game \& Hunt 8(10): 7. Oct.

VAN ZYL, J. 1999. Kies 'n wenplaas met 'n sakeplan. Finansies \& Tegniek 51(41): 30. Nov.

YunIS, E. 2001. Conditions for sustainable ecotourism development and management. [Web:] http://www.world-tourism.org/sustainable/ IYE/Regional_activities/Mozambique/Spee [Date of access: 21 Feb. 2004]. 